\title{
ANALISIS PENGARUH SIKLUS KEUANGAN TERHADAP STABILITAS SISTEM KEUANGAN DI INDONESIA
}

\author{
Setyo Tri Wahyudi* \\ Rihana Sofie Nabella \\ Nurul Badriyah \\ Fakultas Ekonomi dan Bisnis \\ Universitas Brawijaya \\ setyo.tw@ub.ac.id
}

\begin{abstract}
ABSTRAK
Penelitian ini bertujuan untuk mengetahui pengaruh siklus keuangan terhadap stabilitas sistem keuangan di Indonesia. Penelitian ini menggunakan metode analisis data Error Correction Model (ECM). Variabel yang digunakan dalam penelitian ini adalah Indeks Stabilitas Sistem Keuangan (ISSK), Indeks Harga Saham Gabungan (IHSG), Indeks Harga Properti Residual (IHPR), nilai tukar atau kurs dan kredit. Hasil penelitian menunjukkan bahwa Indeks Harga Saham Gabungan (IHSG), Indeks Harga Properti Residual (IHPR) berpengaruh negatif terhadap Indeks Stabilitas Sistem Keuangan (ISSK) baik dalam jangka pendek maupun jangka panjang. Kurs berpengaruh terhadap Indeks Stabilitas Sistem Keuangan (ISSK) dalam jangka pendek, sedangkan untuk jangka panjang tidak berpengaruh. Pertumbuhan kredit tidak berpengaruh terhadap Indeks Stabilitas Sistem Keuangan (ISSK) dalam jangka pendek maupun jangka panjang.
\end{abstract}

Kata Kunci: Siklus Keuangan, Stabilitas Sistem Keuangan, Error Correction Model

\section{PENDAHULUAN}

Siklus keuangan merupakan suatu kondisi dimana kegiatan di sektor keuangan mengalami fase ekspansif yang ditandai dengan akselerasi pertumbuhan kredit perbankan dan pembiayaan yang tinggi, kemudian menuju fase kejenuhan (titik puncak atau peak) dan selanjutnya diikuti fase kontraktif yang ditandai dengan terjadinya penurunan pertumbuhan kredit perbankan dan pembiayaan. Menurut Borio (2012) siklus keuangan dapat didefinisikan sebagai interaksi (financial constraint), yang diterjemahkan sebagai boom yang diikuti oleh bust.

Komponen siklus keuangan setidaknya mewakili dua unsur yaitu, persepsi terhadap nilai dan risiko serta kendala pembiayaan (Alamsyah, 2014). Persepsi terhadap nilai dan risiko diwakili oleh harga aset, misalnya harga properti dan harga saham. Perubahan pada harga aset mencerminkan perilaku agen ekonomi dalam merespon kondisi ekonomi dan keuangan yang terjadi. Sedangkan kendala pembiayaan diwakili oleh kredit dalam arti luas (broad credit) yaitu total pembiayaan untuk sektor swasta yang antara lain diperoleh dari pembiayaan bank, pasar uang, dan utang luar negeri. Kredit bank merupakan sumber pembiayaan terbesar di Indonesia.

Berdasarkan komponen tersebut diketahui bahwa siklus keuangan dapat menangkap naik turunnya pembiayaan yang berkaitan dengan kondisi keuangan. Oleh karena itu, siklus keuangan memiliki kaitan erat dengan sistem keuangan. Alamsyah (2014) menjelaskan bahwa sistem 
keuangan pada prinsipnya adalah kumpulan pasar, institusi, peraturan-peraturan dan teknik-teknik dimana surat berharga diperdagangkan, tingkat bunga ditentukan, dan jasa jasa keuangan dihasilkan dan ditawarkan ke seluruh dunia. Dalam menjalankan fungsinya, sistem keuangan melaksanakan kegiatannya melalui pasar keuangan dan lembaga keuangan.

Ketika pasar keuangan atau lembaga keuangan mengalami hambatan maupun guncangan, maka hal tersebut akan berpengaruh terhadap stabilitas sistem keuangan. MenurutBank Indonesia, stabilitas sistem keuangan adalah sistem keuangan yang stabil yang mampu mengalokasikan sumber dana dan menyerap kejutan (shock) yang terjadi sehingga dapat mencegah gangguan terhadap kegiatan sektor riil dan sistem keuangan. Stabilitas sistem keuangan tersebut dapat dipantau melalui kebijakan mikroprudensial dan makroprudensial guna memitigasi risiko akibat dampak dari terjadinya krisis seperti yang pernah terjadi di Indonesia. Krisis finansial Asia pada tahun 1997/1998 mengakibatkan stabilitas sistem keuangan terguncang. Hal tersebut ditunjukkan melalui indeks stabilitas sistem keuangan yang berada di zona bahaya. Mengingat pentingnya stabilitas system keuangan, penelitian ini bertujuan untuk mengukur pengaruh siklus keuangan terhadap stabilitas sistem keuangan di Indonesia.

\section{TINJAUAN PUSTAKA Siklus Keuangan}

Siklus keuangan merupakan interaksi antara persepsi dari harga (value) dan risiko, perilaku terhadap risiko dan kendala pembiayaan (financial constraint), yang diterjemahkan sebagai boom yang diikuti oleh bust. Selaras dengan Borio, $\mathrm{Ng}$ (2011) menyatakan bahwa siklus keuangan merupakan perubahan persepsi dan sikap terhadap risiko keuangan dari waktu ke waktu. Berdasarkan Stabilitas Keuangan Indonesia dan berbagai penelitian yang telah dilakukan, terdapat 6 karakteristik utama siklus keuangan.

Alamsyah (2014) menjelaskan bahwa komponen siklus keuangan setidaknya memiliki dua unsur. Pertama, persepsi terhadap nilai dan risiko. Persepsi ini biasanya diwakili oleh harga aset, misalnya harga properti, harga saham, harga perumahan, dan lain-lain. Perubahan pada harga aset mencerminkan bahwa perilaku agen ekonomi dalam merespon kondisi ekonomi yang sedang terjadi. Komponen kedua ialah kendala pembiayaan. Kendala pembiayaan ini diwakili oleh kredit dalam arti luas yang sering disebut (broad credit). Menurut Bank Indonesia, broad credit merupakan pembiayaan untuk sektor swasta yang antara lain diperoleh dari pembiayaan bank, pasar uang seperti penerbitan saham dan surat berharga, serta utang luar negeri. Kredit yang didapat dari bank merupakan pembiayaan terbesar di Indonesia. Oleh karena itu, siklus keuangan biasanya menggunakan broad credit. Dengan menggunakan broad credit, siklus keuangan memiliki kelebihan dalam menangkap pengaruh dari eksternal yang tercermin dalam utang luar negeri dan posisi penjualan surat berharga yang sebagian dimiliki oleh asing.

Borio (2012) menjelaskan bahwa, karakteristik siklus keuangan pertama yang menonjol ialah perilaku kredit dan harga properti. Claessens et al. (2011) mengungkapkan bahwa kredit merupakan penghubung utama antara tabungan dan investasi. Selain itu, Claessens et al. (2011) dan Drehman et al. (2012) menyatakan bahwa harga properti cenderung naik pada masa ekspansi kredit dan menurun pada masa kontraksi kredit. Siklus keuangan ratarata memiliki durasi kurang lebih 38 sampai dengan 39 triwulan. Berdasarkan penelitian yang dilakukan Drehmann et al. (2012), krisis umumnya terjadi tidak jauh dari peak pada siklus keuangan. Siklus keuangan juga dapat mendeteksi risiko tekanan keuangan lebih awal sekitar satu tahun. 
Untuk panjang dan amplitudo pada siklus keuangan biasanya dipengaruhi oleh rezim kebijakan yang berlaku. Karakteristik yang terakhir ialah determinan siklus keuangan menunjukkan total pembiayaan suatu perekonomian.

\section{Stabilitas Sistem Keuangan}

Bank Indonesia menyatakan bahwa stabilitas sistem keuangan adalah sistem keuangan yang stabil yang mampu mengalokasikan sumber dana dan menyerap kejutan (shock) yang terjadi sehingga dapat mencegah gangguan terhadap kegiatan sektor riil dan sistem keuangan. Menteri Keuangan turut mengemukakan faktor-faktor yang dapat mendukung terciptanya stabilitas sistem keuangan, yakni lingkungan ekonomi makro yang stabil, lembaga keuangan yang dikelola dengan baik, pengawasan institusi keuangan yang efektif serta memiliki sistem pembayaran yang aman dan handal. Dalam menjaga stabilitas sistem keuangan, Bank Indonesia menjalankan empat strategi yaitu pemantapan regulasi dan standar, peningkatan riset dan surveilance, peningkatan kondisi dan kerjasama, serta penetapan jaring pengaman dan penyelesaian krisis.

Pemantauan stabilitas sistem keuangan melalui mikroprudensial, dilakukan terhadap kondisi mikro institusi keuangan dalam sistem keuangan. Perbankan, sebagai salah satu institusi keuangan merupakan sektor yang termasuk mikroprudensial. Melalui pemantauan yang dilakukan terhadap perbankan, risiko likuiditas, risiko pasar, risiko kredit, dan rentabilitas institusi keuangan dapat diketahui. Dalam mengukur konsep risiko pada perspektif mikroprudensial, risiko diukur dari tingkat kesehatan dan kinerja setiap institusi keuangan.

Pemantauan indikator makroprudensial dilakukan terhadap kondisi sistem keuangan secara keseluruhan sebagai kumpulan dari individu lembaga keuangan. Pada perspektif ini, risiko diukur dari spillover dampak dan biaya yang ditimbulkan, termasuk interaksi dengan makroekonomi. Kesehatan dan kinerja institusi keuangan tidak lagi menjadi syarat "perlu" bagi stabilitas sistem keuangan apabila kegagalan/risiko pada satu atau beberapa institusi tidak menimbulkan dampak signifikan pada sistem. Kebijakan makroprudensial perlu dilakukan guna menghindari risk taking behavior, procyclical, interconnectedness, dan contagion/spillover.

\section{Penelitian Terdahulu}

Penelitian mengenai pentingnya siklus keuangan telah banyak dilakukan oleh peneliti sebelumnya. Claesens (2010) melakukan penelitian dengan judul "Financial Cycles: What? How? When?". Penelitian tersebut bertujuan untuk mengetahui apa yang dimaksud dengan siklus keuangan, bagaimana siklus keuangan dapat terjadi, dan kapan siklus keuangan terjadi pada 21 negara dari tahun 1960 hingga 2007. Hasil penelitian tersebut adalah siklus keuangan sering terjadi pada periode sebelum globalisasi terutama pada harga saham, dimana fase ekspansi memiliki durasi yang lebih panjang dibandingkan fase kontraksi.

Selanjutnya, penelitian yang dilakukan oleh Borio (2014) dengan judul "The Financial Cycle and Macroeconomics: What Have We Learnt?". Tujuan dari penelitian tersebut adalah untuk mengetahui dan menganalis terkait siklus keuangan. Hasil yang diperoleh adalah siklus keuangan merupakan sarana yang tepat untuk melihat pergerakan kredit dan harga properti dimana siklus keuangan memiliki durasi dan amplitudo yang lebih panjang dibandingkan dengan siklus bisnis. Hal tersebut memungkinkan siklus keuangan untuk mengidentifikasi risiko krisis keuangan di masa depan secara real time.

Barbone (2015) melakukan penelitian yang berjudul "Business and Financial Cycles: An Estimation of Cycles Length Focusing on Macroprudential Policy". Tujuan dari penelitian ini adalah untuk menganalisis siklus bisnis dan siklus keuangan pada 28 negara dalam kurun waktu 13 hingga 20 
tahun. Hasil yang diperoleh adalah rata-rata panjang siklus keuangan sekitar 13,8 tahun sedangkan siklus bisnis 3 hingga 7,5 tahun. Selanjutnya, penelitian yang dilakukan oleh Chang (2016) dengan judul "Financial Soundness Indicator, Financial Cycle, Credit Cycle and Business Cycle - Evidence from Taiwan". Penelitian ini bertujuan untuk menganlisis indikator stabilitas keuangan, siklus keuangan, siklus kredit, dan siklus bisnis pada negara Taiwan. Hasil yang diperoleh adalah kredit selaras dengan indeks real estate dan kegiatan ekonomi riil dimana kesehatan perbankan memburuk selama fase ekspansi dan fase kontraksi.

Ólafsson (2016) melakukan penelitian yang berjudul "Financial Cycle in Iceland: Characteristics, Spillovers, and Cross-border Channel". Tujuan dari penelitian ini ialah untuk menganalisis karakteristik, spillover dan cross-border pada siklus keuangan Islandia. Hasil penelitian menunjukkan bawa siklus keuangan Islandia memainkan peran penting dalam perkembangan ekonomi makro dan krisis keuangan sekitar 130 tahun. Hal ini merupakan bukti kuat akibat spillover siklus keuangan global.

\section{METODE ANALISIS}

Penelitian ini menggunakan pendekatan kuantitatif. Jenis data yang digunakan dalam penelitian ini adalah data sekunder. Sumber data diperoleh dari laporan Bank Indonesia dan Otoritas Jasa Keuangan. Penelitian ini menggunakan data triwulanan dengan periode tahun 1996 hingga 2016. Penelitian ini bertujuan untuk mengetahui bagaimana pengaruh siklus keuangan terhadap stabilitas sistem keuangan di Indonesia periode 1996 hingga 2016. Sehubungan dengan hal tersebut, metode analisis data yang digunakan adalah Error Correction Model (ECM). Data yang tidak stasioner seringkali menunjukkan hubungan ketidakseimbangan dalam jangka pendek, tetapi ada kecenderungan terjadinya keseimbangan hubungan jangka panjang. Selanjutnya dilakukan uji kointegrasi untuk mengetahui ada tidaknya hubungan jangka panjang di dalam variabel ekonomi yang diteliti. Kemudian akan diterapkan model koreksi kesalahan (ECM) untuk mengoreksi adanya ketidakseimbangan tersebut.

Variabel penelitian terdiri dari variabel indeks stabilitas sistem keuangan (ISSK), indeks harga saham gabungan (IHSG), indeks harga perumahan residensial (IHPR), kurs dan pertumbuhan kredit. Adapun definisi operasional dari masing-masing variabel adalah sebagai berikut: 1) Indeks Stabilitas Sistem Keuangan (ISSK): pengukuran yang digunakan untuk mengamati stabilitas keuangan pada suatu negara. Semakin tinggi indeks stabilitas keuangan suatu negara, maka semakin tinggi tekanan pada stabilitas sistem keuangan. 2) Indeks Harga Saham Gabungan (IHSG): indikator pergerakan harga saham di Bursa Efek Indonesia. IHSG digunakan oleh investor sebagai salah satu pedoman dalam berinvestasi di Pasar Modal. 3) Indeks Harga Perumahan Residensial (IHPR): salah satu indikator ekonomi yang memberikan informasi mengenai perkembangan properti residensial. 4) Kurs: harga suatu mata uang terhadap mata uang lainnya atau nilai dari suatu mata uang terhadap mata uang lainnya. 5) Pertumbuhan kredit: kredit merupakan pinjaman yang diberikan oleh kreditur kepada debitur dimana waktu pengembaliannya disesuaikan dengan kesepakatan antara kedua belah pihak.

Variabel dependen pada penelitian ini adalah indeks stabilitas sistem keuangan. Variabel independen pada penelitian ini adalah IHSG, IHPR, kurs dan kredit. Untuk itu, persamaan model estimasi jangka panjang dalam penelitian ini adalah:

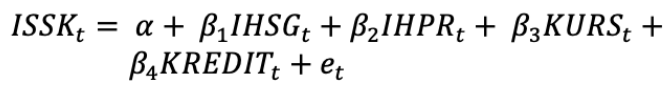

Selanjutnya, persamaan tersebut diestimasi menggunakan metode Error Correction Model (ECM) yang disertai dengan residual jangka panjang sebagai 
variabel Error Correction Term (ECT). Secara umum model ECM jangka pendek sebagai berikut:

$$
\begin{aligned}
\text { DISSK }_{t}= & \alpha+\beta_{1} D_{I H S G_{t}}+\beta_{2} \text { DIHPR }_{t}+ \\
& \beta_{3} D K U R S_{t}+\beta_{4} D K R E D I T_{t}+\gamma E C T+e_{t}
\end{aligned}
$$

\section{HASIL DAN PEMBAHASAN}

\section{Uji Stasioneritas Data dan Uji Derajat} Integrasi

Uji stasioneritas data dapat dilihat dengan uji Augmented Dickey Fuller (ADF). Pengujian ADF didasarkan pada nilai prob Schward Info Criterion (SIC). Apabila nilai prob kurang dari $\alpha(0,05)$ maka data tersebut dinyatakan stasioner. Namun, apabila nilai prob lebih dari $\alpha(0,05)$ maka data tersebut dinyatakan tidak stasioner pada derajad level $(I(0))$. first difference (I(1)). Data tidak stasioner pada derajat yang sama akan menimbulkan regresi lancung (spurious regression) sehingga perlu disamakan terlebih dahulu.

Pada tabel 2 dapat dilihat bahwa setelah dilakukan uji stasioner pada tingkat first difference data yang digunakan pada penelitian ini semua stasioner pada derajat tersebut.

\section{Uji Kointegrasi}

Uji kointegrasi dilakukan untuk memperoleh hubungan jangka panjang yang stabil antara variabel-variabel yang terintegrasi pada derajad yang sama. Jika variabel dalam penelitian terbukti terkontegrasi maka terdapat hubungan yang stabil dalam jangka panjang.

\begin{tabular}{|c|c|c|c|}
\hline Variabel & Nilai Prob & $\alpha(0,05)$ & Keterangan \\
\hline ISSK & 0.0229 & 0.05 & Stasioner \\
\hline IHSG & 0.6510 & 0.05 & Tidak stasioner \\
\hline IHPR & 0.9859 & 0.05 & Tidak stasioner \\
\hline KURS & 0.1468 & 0.05 & Tidak stasioner \\
\hline LN_KREDIT & 0.8250 & 0.05 & Tidak stasioner \\
\hline
\end{tabular}

Tabel 1. Hasil Uji Stasioner pada Derajat Level

Sumber : Data diolah, 2018

\begin{tabular}{|c|c|c|c|}
\hline Variabel & Nilai Prob & $\alpha(0,05)$ & Keterangan \\
\hline ISSK & 0.0000 & 0.05 & Stasioner \\
\hline IHSG & 0.0000 & 0.05 & Stasioner \\
\hline IHPR & 0.0000 & 0.05 & Stasioner \\
\hline KURS & 0.0000 & 0.05 & Stasioner \\
\hline LN_KREDIT & 0.0001 & 0.05 & Stasioner \\
\hline
\end{tabular}

Tabel 2. Hasil Uji Stasioner pada Derajat First Difference

Sumber : Data diolah, 2018

Dari hasil uji stasioner pada tingkat level, pada tabel 1 menunjukkan bahwa variabel IHSG, IHPR, KURS dan LN_KREDIT tidak stasioner pada derajat level. Oleh karena itu perlu dilakukan transformasi

Berdasarkan tabel 3, variabel IHSG memiliki nilai prob sebesar $0.02<$ nilai a (0.05) maka Ho ditolak, artinya IHSG data (differencing) dengan menurunkan 
Tabel 3. Hasil Estimasi dalam Jangka Panjang

Dependent Variable: ISSK

\begin{tabular}{llcrl}
\hline \multicolumn{1}{c}{ Variabel } & Coef. & \multicolumn{1}{l}{ Std. Error } & \multicolumn{1}{l}{ t-Stat. } & Prob. \\
\hline IHSG & -0.00536 & 0.002260 & -2.37235 & 0.0201 \\
IHPR & $-825 E-0$ & $3.80 E-05$ & -2.17234 & 0.0328 \\
KURS & $414 E-05$ & $1.34 E-05$ & 3.082217 & 0.0028 \\
LN_ & 0.083194 & 0.049808 & 1.670276 & 0.0988 \\
KREDIT & & & & \\
C & 0.500589 & 0.681015 & 0.735063 & 0.4645 \\
\hline Prob & & 0.000068 & & \\
(F-Statistic) & & & & \\
R-squared & & 0.262363 & &
\end{tabular}

Sumber : Data diolah, 2018

Tabel 4. Hasil Pengujian Stasioner Residual Variabel Dependen

\begin{tabular}{cccc}
\hline Variabel & Nilai Prob & $\alpha(0,05)$ & Keterangan \\
\hline RESID01 & 0.0036 & 0.05 & Stasioner \\
\hline
\end{tabular}

Sumber : Data diolah, 2018

berpengaruh terhadap stabilitas sistem keuangan di Indonesia dalam jangka panjang dan nilainya negatif dengan nilai koefisien sebesar -0.005361. Artinya dalam jangka panjang, setiap ada kenaikan 1 satu perubahan IHSG maka akan menyebabkan penurunan stabilitas sistem keuangan sebesar 0.005361. Variabel IHPR memiliki nilai prob sebesar $0.03<$ nilai a (0.05) maka Ho ditolak, artinya IHPR berpengaruh terhadap stabilitas sistem keuangan di Indonesia dalam jangka panjang dan nilainya negatif dengan nilai koefisien sebesar -825E05. Artinya dalam jangka panjang setiap ada kenaikan 1 satu perubahan IHPR maka akan menyebabkan penurunan stabilitas sistem keuangan sebesar 825E-05.

Kemudian, variabel KURS memiliki nilai prob sebesar 0.002 < nilai a (0.05) maka Ho ditolak, artinya kurs berpengaruh terhadap stabilitas sistem keuangan di Indonesia dalam jangka panjang dan nilainya positif dengan nilai koefisien sebesar 414E-05. Artinya dalam jangka panjang, setiap ada kenaikan atau apresiasi 1 satu perubahan kurs maka akan menyebabkan kenaikan stabilitas sistem keuangan sebesar 414E05. Variabel LN_KREDIT memiliki nilai prob sebesar $0.09>$ nilai a (0.05) maka Ho diterima, artinya LN_KREDIT tidak berpengaruh terhadap stabilitas sistem keuangan di Indonesia dalam jangka panjang.

Terlihat nilai Prob F-Statistic sebesar 0.000 < nilai a (0.05) maka Ho ditolak, artinya seluruh variabel secara bersamasama berpengaruh terhadap stabilitas sistem keuangan dalam jangka panjang. Nilai R-squared sebesar 0.262363 , artinya dalam jangka panjang kemampuan variabel independen dalam mempengaruhi ISSK di Indonesia sebesar 26,23\%, sedangkan sisanya $73.77 \%$ dijelaskan oleh error, dalam hal ini variabel di luar penelitian. Setelah dilakukan estimasi jangka panjang, kemudian didapat residual dari hasil estimasi. Kemudian dilakukan pengujian unit root atau uji stasioneritas pada residual di tingkat level untuk melihat apakah persamaan tersebut telah terkointegrasi atau memiliki keseimbangan dalam jangka panjang. Residual tersebut nantinya akan

EKOBIS Vol. 20, No.2, Juli 2019 : 87 - 95 
diestimasi dalam jangka pendek sebagai variabel Error Correction Term (ECT). Hasil pengujian residual tersebut adalah sebagai berikut.

Berdasarkan tabel 4 yang merupakan hasil pengujian residual dengan variabel dependen ISSK, terlihat bahwa nilai prob lebih kecil daripada nilai $\alpha$. Hasil tersebut menyatakn bahwa residual dalam jangka panjang telah stasioner di tingkat level.

\section{Estimasi Error Correction Model}

Model ECM mempunyai ciri khas dengan dimasukkannya unsur Error Correction Term (ECT)/Residual dalam model. Nilai koefisien ECT dapat memengaruhi seberapa cepat atau lambat keseimbangan dapat tercapai kembali. Untuk persamaan jangka pendek, ditunjukkan oleh nilai speed of adjustment atau koefisien dari resid(-1). Nilai koefisien tersebut harus negatif dan signifikan (probabilitasnya berada di bawah 0.05). Kemudian setelah spesifikasi model valid, dilanjutkan dengan pengujian hipotesis serta menentukan hubungan variabel dalam jangka pendek dan jangka panjang.

Tabel 5. Hasil Estimasi ECM

\begin{tabular}{|c|c|c|c|c|}
\hline Variable & Coeff. & $\begin{array}{l}\text { Std. } \\
\text { Error }\end{array}$ & t-Stat. & Prob. \\
\hline C & & & & 0.2499 \\
\hline $\mathrm{D}(\mathrm{IHSG})$ & & & & 0.0202 \\
\hline $\mathrm{D}(\mathrm{IHPR})$ & & $\begin{array}{r}8.02 \mathrm{E}- \\
05\end{array}$ & & 0.0000 \\
\hline $\mathrm{D}(\mathrm{KURS})$ & $\begin{array}{r}6.90 \mathrm{E}- \\
06\end{array}$ & $\begin{array}{r}1.95 \mathrm{E}- \\
05\end{array}$ & & 0.7242 \\
\hline $\begin{array}{l}\mathrm{D}\left(\mathrm{LN}_{-}\right. \\
\text {KREDIT) }\end{array}$ & & & & 0.6213 \\
\hline ECT & & & & 0.0001 \\
\hline $\begin{array}{l}\text { Prob } \\
\text { (F-Statistic) }\end{array}$ & \multicolumn{4}{|c|}{0.000004} \\
\hline R-squared & & 0.34 & 159 & \\
\hline
\end{tabular}

Sumber : Data diolah, 2018
Berdasarkan tabel 5 terlihat bahwa nilai $\mathrm{R}$-squared sebesar 0.340159 , artinya dalam jangka pendek kemampuan variabel independen dalam mempengaruhi stabilitas sistem keuangan di Indonesia sebesar $34,01 \%$, sedangkan sisanya dijelaskan oleh error. Dari hasil estimasi ECM ditemukan bahwa variabel IHSG memiliki nilai prob sebesar 0.02 < nilai a (0.05) maka Ho ditolak, artinya IHSG berpengaruh terhadap stabilitas sistem keuangan di Indonesia dalam jangka pendek dan nilainya negatif dengan nilai koefisien sebesar 0.005752 . Artinya dalam jangka pendek, setiap ada kenaikan 1 satu perubahan IHSG maka akan menyebabkan penurunan stabilitas sistem keuangan sebesar 0.005752 .

Variabel IHPR memiliki nilai prob sebesar $0.00<$ nilai $\alpha(0.05)$ maka Ho ditolak, artinya IHPR berpengaruh terhadap stabilitas sistem keuangan di Indonesia dalam jangka pendek dan nilainya negatif dengan nilai koefisien sebesar 0.000354 . Artinya dalam jangka pendek, setiap ada kenaikan atau apresiasi 1 satu perubahan kurs maka akan menyebabkan kenaikan stabilitas sistem keuangan sebesar 0.000354 . Variabel KURS memiliki nilai prob sebesar $0.72>$ nilai a (0.05) maka Ho diterima, artinya KURS tidak berpengaruh terhadap stabilitas sistem keuangan di Indonesia dalam jangka pendek. Sedangkan, variabel LN_ KREDIT memiliki nilai prob sebesar 0.62 $>$ nilai a (0.05) maka Ho diterima, artinya LN_KREDIT tidak berpengaruh terhadap stabilitas sistem keuangan di Indonesia dalam jangka pendek.

Pada persamaan model dengan variabel dependen ISSK, nilai ECT (residual) adalah -0.314260 dengan nilai probabilitas 0.0001 $<0.05$ yang berarti signifikan. Nilai koefisien ECT bertanda negatif dan signifikan secara statistik yang berarti model spesifikasi ECM yang digunakan dalam penelitian ini valid. Nilai koefisen ECT sebesar -0.314260 mempunyai makna bahwa $-0.314260 \%$ dari ketidaksesuaian yang dapat dikoreksi jangka pendek terhadap jangka panjang 
disesuaikan dalam waktu selama 31 triwulan.

\section{Pembahasan Hasil}

Berdasarkan pengujian model, disebutkan bahwa dalam jangka pendek dan jangka panjang Indeks Harga Saham Gabungan (IHSG) berpengaruh negatif dan signifikan terhadap stabilitas sistem keuangan dalam rentang waktu penelitian yaitu tahun 1996 hingga 2016. Hal ini sesuai dengan hipotesis penelitian yang menyatakan bahwa adanya penurunan stabilitas sistem keuangan yang disebabkan oleh kenaikan indeks harga saham gabungan. Perubahan pada harga aset mencerminkan perilaku agen ekonomi dalam merespon kondisi ekonomi dan keuangan yang terjadi. Pada tahun 2016, pasar modal Indonesia (BEI) didominasi oleh investasi asing sebesar $64 \%$ yang mengakibatkan keuntungan investasi tersebut akan lari ke luar negeri sehingga dapat mengganggu kestabilan sistem keuangan dalam negeri.

Kemudian, variabel Indeks Harga Perumahan Residensial(IHPR) dalamjangka pendek dan jangka panjang menunjukkan pengaruh negatif dan signifikan terhadap stabilitas sistem keuangan dalam rentang waktu penelitian yaitu tahun 1996 hingga 2016. Hal ini sesuai dengan hipotesis penelitian yang menyatakan bahwa adanya penurunan stabilitas sistem keuangan yang disebabkan oleh kenaikan indeks harga perumahan residensial. Berdasarkan laporan Bank Indonesia 2016, harga perumahan residensial terus mengalami kenaikan. Perkembangan tersebut dikhawatirkan akan mendorong harga rumah menjadi semakin mahal dan sulit terjangkau oleh masyarakat berpendapatan rendah. Tingginya harga rumah juga dapat mendorong peningkatan nilai KPR melalui pembiayaan perbankan. Hal ini berpotensi memicu instabilitas atau tidak stabil di sektor perbankan. Tidak stabilnya sektor perbankan akan berpengaruh terhadap stabilitas sistem keuangan.
Selanjutnya, hasil estimasi ECM dalam jangka pendek menunjukkan bahwa kurs berpengaruh positif tetapi tidak signifikan terhadap stabilitas sistem keuangan. Namun, pada jangka panjang kurs berpengaruh positif signifikan terhadap stabilitas sistem keuangan. Hal ini berarti menolak hipotesis penelitian yang menyatakan bahwa adanya pengaruh kurs maka akan menyebabkan penurunan stabilitas sistem keuangan. Kurs menekankan kepada pentingnya aspek perubahan harga aset finansial terhadap aktivitas perekonomian. Apresiasi nilai tukar atau kurs akan meningkatkan stabilitas sistem keuangan.

Pertumbuhan kredit berdasarkan hasil estimasi ECM menunjukkan adanya pengaruh positif tetapi tidak signifikan dalam jangka pendek dan jangka panjang. Hal ini berarti menolak hipotesis penelitian yang menyatakan bahwa pengaruh peningkatan pertumbuhan kredit maka akan menyebabkan penurunan stabilitas sistem keuangan. Pertumbuhan kredit tidak memiliki pengaruh pada stabilitas sistem keuangan disebabkan oleh menurunnya pertumbuhan kredit. Turunnya pertumbuhan kredit tersebut diikuti oleh turunnya risiko kredit atau Non Performing Loan (NPL). Berdasarkan Laporan Perekonomian Indonesia 2015, NPL secara umum mengalami penurunan sebesar 2,5 dibandingkan tahun sebelumnya sebesar 2,8. Turunnya NPL ini tentunya membuat risiko kredit turun dan kondisi keuangan akan stabil.

\section{SIMPULAN}

Berdasarkan hasil penelitian dapat disimpulkan bahwa pertama, naiknya indeks harga saham gabungan dan indeks harga perumahan residensial akan menurunkan stabilitas sistem keuangan. Kedua, dalam jangka pendek apresiasi kurs akan meningkatkan stabilitas sistem keuangan. Kemudian, ketiga, turunnya pertumbuhan kredit tidak mempengaruhi perubahan stabilitas sistem keuangan. 


\section{DAFTAR PUSTAKA}

Alamsyah, Halim. Adamanti, Justina. Yumanita, Diana. Indah, Rieska Astuti. 2014. Working Paper: Siklus Keuangan Indonesia. Bank Indonesia.

Barbone, Rodrigo G. Lima, Joaquim. Marinho, Leonardo. 2015. Business and Financial Cycles: An Estimation of Cycles Length Focusing on Macroprudential Policy.

Biro Stabilitas Sistem Keuangan. 2013. Penggunaan Indeks Stabilitas Sistem Keuangan (ISSK) Dalam Pelaksanaan Surveilans Makroprudensial. Bank Indonesia.

Bordo MD, Dueker MJ, Wheelock DC. 2001. Aggregate Price Shocks and Financial Instability: A Historical Analysis. Federal Reserve Bank of St. Louis.

Borio, C. Drehmann, M. 2009a. Towards an Operational Framework for Financial Stability: 'Fuzzy' Measurement and Its Concequences. Banco Central de Chile.

Borio, Claudio. 2012. The Financial Cycle and Macroeconomics: What Have We Learnt?

Chang, Yuan. 2016. Financial Soundness Indicator, Financial Cycle and Business Cycle.

Claesens, Stijn. Kose, M.Ayhan. E, Marco Terrones. 2011. Financial Cycles: What? How? When? International Monetary Fund.

Drehmann, M. Borio, C. Tsatsaronis, Kostas. 2012. Characterizing the Financial Cycle: Don't Lose Sight of The Medium Term. Bank for International Settlements.

$\mathrm{Ng}$, Tim. 2011. The Predictive Content of Financial Cycle Measures for Output Fluctuations. Bank for International Settlements.

Ólafsson, T. Tjörvi. 2016. Financial Cycle in Iceland: Characteristics, Spillovers, and CrossBorder Channel. Central Bank of Iceland.

Widarjono, Agus. 2013. Ekonometrika Pengantar dan Aplikasinya. Yogyakarta: Ekonisia. 